\title{
Effect of silicon application on wheat (Triticum aestivum L.) growth under water deficiency stress
}

\author{
Faraz Ahmad $^{1}$, Rahmatullah ${ }^{1}$, Tariq Aziz ${ }^{2}$, M. Aamer Maqsood ${ }^{1}$, \\ Mukkram A. Tahir ${ }^{1}$ and Shamsa Kanwal ${ }^{1}$ \\ ${ }^{1}$ Institute of Soil \& Environmental Sciences, University of Agriculture, Faisalabad \\ ${ }^{2}$ Sub-Campus Depalpur, University of Agriculture, Faisalabad, Depalpur, Okara
}

\begin{abstract}
Silicon is known to ameliorate the deleterious effects of drought on plant growth. We evaluated growth of wheat (CV. Inqlab-91) on different soil water regimes as affected by $\mathrm{Si}$ application. Silicon was added in soil @ $50 \mathrm{mg} / \mathrm{kg}$ and $150 \mathrm{mg} / \mathrm{kg}$ of soil. Plants were grown with three levels of soil water contents viz $50 \%, 75 \%$ and $100 \%$ of field capacity. Water deficiency in soil significantly reduced shoot biomass and spike weight of wheat plants. Silicon application significantly $(\mathrm{p}<0.01)$ increased plant biomass, plant height and spike weight at all levels of water contents. Poor growth of plants in water deficient conditions was significantly improved with Si application. Silicon application significantly increased Si concentration and uptake in wheat plants grown at all three soil water levels. Mechanisms underlying growth improvement under drought are still unclear and must be explored.
\end{abstract}

Keywords: Drought, silicon, wheat.

\section{تأٔثير إضلكة اللسيلكهن عل الفمح (Triticum aestivum L.) المزوع تهت تأثير الأجهاد المائي}

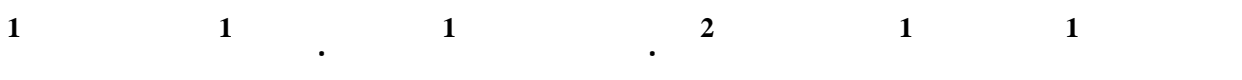

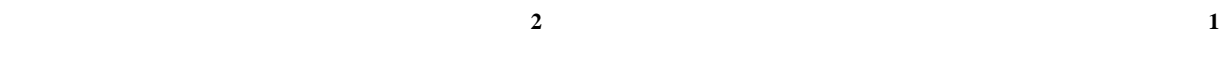

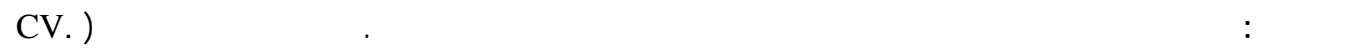

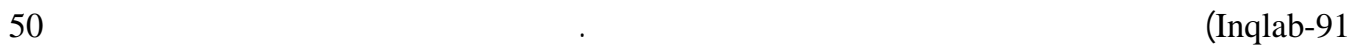

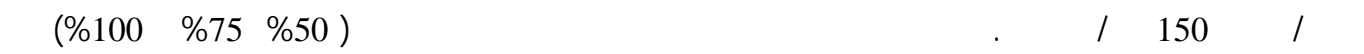

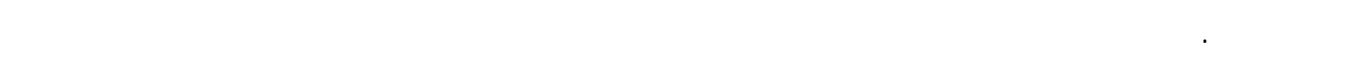

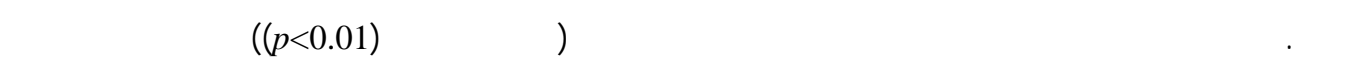

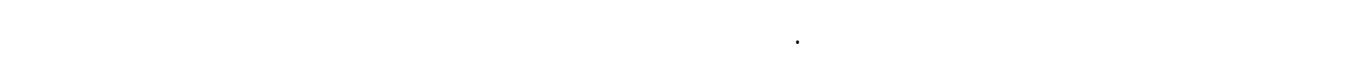

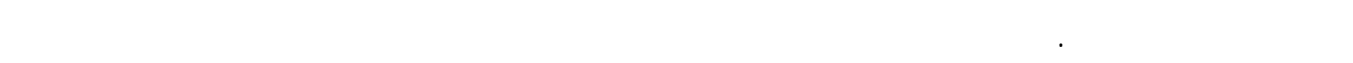

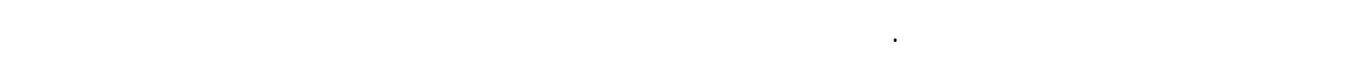

$$
\text { الكاملت الففتلحية: الجفلف ،سيليكون، القمح. }
$$

\section{Introduction}

Silicon, the second most abundant element in the earth's crust, has not yet received the title of essential nutrient for higher plants, as its role in plant biology is poorly understood (Epstein, 1999). However, various studies have demonstrated that $\mathrm{Si}$ application increased plant growth significantly (Alvarez and Datnoff, 2001). Beneficial effects of Si are more prominent when plants were 
subjected to multiple stresses including biotic and abiotic stresses (Aziz et al., 2002; Rodrigues et al., 2003; Мa, 2004; Tahir et al., 2006). Silicon is also known to increase drought tolerance in plants by maintaining plant water balance, photosynthetic activity, erectness of leaves and structure of xylem vessels under high transpiration rates (Melo et al., 2003; Hattori et al., 2005). Gong et al., (2003) observed improved water economy and dry matter yield of water by $\mathrm{Si}$ application. Silicon application is reported to enhance leaf water potential under water stress conditions (Matoh et al., 1991). They suggested that a silica-cuticle double layer formed on leaf epidermal tissue is responsible for this higher water potential. Lux et al. (2002) reported that endodermal tissue accumulates large amounts of Si in drought tolerant cereal cultivars. Results of Hattori et al. (2003) and Lux et al. (2003) suggested that Si plays an important role in water transport and root growth under drought conditions in sorghum.

Certain cereal crops especially from the Gramineae and Cyperaceae families accumulate large amounts of Si (Mitani and Ma, 2005), and Si application to these crops ensured better growth. Being a member of Gramineae family, wheat is also considered as Si accumulator. Wheat is the major staple food of the people of Pakistan. Wheat, being a single largest crop of the rainfed areas, contributes $12.5 \%$ to the national wheat production (Alvi and Shrif, 1995). Average wheat yield under rainfed conditions is very low ( $<600 \mathrm{~kg} / \mathrm{acre})$ compared to irrigated wheat ( 1200 kg/acre). Among major yield limiting factors, drought is very important as it seriously affects plant growth, yield and mineral nutrition (Garg et al., 2004; Samarah et al., 2004). To ensure food security and sustainable economy, it is extremely important to find ways to improve drought tolerance of wheat. Keeping in view the importance of wheat, we evaluated the beneficial effects of Si application on wheat growth under different soil water contents.

\section{Material and Methods}

The experiment was conducted in a rain protected wire house under normal conditions. The bulk sample of surface soil (sandy clay loam) was collected from the Institute Research Area, University of Agriculture, Faisalabad. The soil was air dried and ground to pass through a $5 \mathrm{~mm}$ sieve. $4.5 \mathrm{~kg}$ of prepared soil was put in plastic pots. Nitrogen, phosphorus and potassium were mixed in every pot @ 80, 60 and $50 \mathrm{mg} \mathrm{kg}-1$, respectively. Silicon was added in the soil @ 50 and 150 mg kg-1 of soil to each half of the pots using sodium silicate (after dissolving it in 50\% $\mathrm{NaOH}$ and $\mathrm{H}_{2} \mathrm{O}_{2}$ ). The experimental design was CRD with three replicates of each treatment.

A commonly grown wheat cultivar, Inqlab-91, was selected for the present study because it is drought sensitive (Akram et al., 2004). Ten seeds of wheat were sown per pot and reduced to four plants per pot after fifteen days of seedling emergence. Distilled water was used for irrigation and all of the pots were kept at field capacity till $15 \mathrm{~d}$. Three moisture levels viz 50\%, $75 \%$ and $100 \%$ of field capacity were then maintained in these pots till harvesting. After 75 days, height of plants was measured from the surface of soil by using measuring tape. After measuring plant height, the plants were harvested and washed thoroughly with distilled water. After 2 days of air drying, samples were oven dried at $70^{\circ} \mathrm{C}$ in a forced air driven oven and dry weight was recorded. The dried samples were ground in a grinding mill to fine powder and mixed thoroughly. Samples (0.20 g) were digested in $50 \% \mathrm{NaOH}$ and $50 \%$ $\mathrm{H}_{2} \mathrm{O}_{2}$ in open vessels (Teflon beakers) on a hot plate at $150^{\circ} \mathrm{C}$ for $2 \mathrm{~h}$. The digest was used for Si estimation by the colorimetric molybdenum blue method (Elliot and Snyder, 1991). To $1 \mathrm{ml}$ of supernatant 
filtrate liquid, $25 \mathrm{ml}$ of $20 \%$ acetic acid, $10 \mathrm{ml}$ of ammonium moblybdate (54 g/L) solution was added in a $50 \mathrm{ml}$ polypropylene volumetric flask. After 5 minutes, $5 \mathrm{ml}$ of $20 \%$ tartaric acid and $1 \mathrm{ml}$ of reducing solution was added to the flask and the volume was made up with $20 \%$ citric acid. After half an hour, the absorbance was measured at $650 \mathrm{~nm}$ with a spectrophotometer (Shimadzu, Japan). The reducing agent was prepared by dissolving $1 \mathrm{~g} \mathrm{Na}_{2} \mathrm{SO}_{3}$, 0.5 g 1 amino-2naphthol-4-sulfonic acid and $30 \mathrm{~g}$ $\mathrm{NaHSO}_{3}$ in $200 \mathrm{ml}$ water. The data was analyzed statistically using MSTAT-C software (Russel and Eisensmith, 1983).

\section{Results and Discussion}

\section{Biomass Production}

There were significant main and interactive effects of water contents (WC) and silicon ( $\mathrm{Si}$ ) application on shoot dry matter (SDM) (Table 1). A gradual decrease in WC from $100 \%$ field capacity $\left(\mathrm{FC}_{3}\right)$ to $75 \%\left(\mathrm{FC}_{2}\right)$ and $50 \%$ (FC1) caused a significant decrease $(\mathrm{p}<0.01)$ in SDM, averaged over both Si levels. The plants grown at FC3 and FC2 produced $67 \%$ and $82 \%$ of their SDM when grown with $100 \%$ FC, respectively. Gunes, et al. (2006) reported significant decrease in dry matter production in chickpeas under drought stress. Shoot dry matter production of the plants grown with 150 $\mathrm{mg} / \mathrm{kg} \quad \mathrm{Si}$ was significantly $(\mathrm{p}<0.01)$ higher than those grown with $50 \mathrm{mg} / \mathrm{kg} \mathrm{Si}$ in soil (Table 1) at all levels of soil WC. Maximum increase in SDM due to applied Si was observed when plants were grown with lowest WC in soil (FC1) (Fig. 1). The Increase in SDM due to applied $\mathrm{Si}$ at FC2 and FC3 was almost the same. This indicated that application of $\mathrm{Si}$ improved SDM significantly but increase was more profound when plants were suffering water stress (FC1). Rafi et al. (1997) and Hattori et al. (2005) also reported significant improvement in plant biomass by Si application under drought stress. Gong et al. (2003) reported lower transpiration rate, greater leaf weight ratio and lower specific leaf area of $\mathrm{Si}$ fed wheat plants under water stress condition. It may be the reason for increased photosynthesis and dry matter production by Si application under dry conditions.

There were significant $(\mathrm{p}<0.01)$ main and interactive effects of soil WC and $\mathrm{Si}$ levels on plant height (Table 1). Plant height was significantly more in plants grown with higher WC (FC3) $(58.6 \mathrm{~cm})$ than those grown with FC2 $(47.6 \mathrm{~cm})$ and FC1 $(39.3 \mathrm{~cm})$. Averaged on all WC, plant height was more when $\mathrm{Si}$ was applied@150 mg/kg than those supplied with $50 \mathrm{mg} / \mathrm{kg} \mathrm{Si}$. The height of wheat plants grown with $50 \mathrm{mg} / \mathrm{kg}$ of Si ranged from $37.7 \mathrm{~cm}$ in FC1 to $57.7 \mathrm{~cm}$ in the FC2 treatment. Silicon application significantly improved plant height under drought conditions. In Si fed plants, plant height ranged from 41.1 in FC1 to 61.7 $\mathrm{cm}$ in the FC3 treatment.

There was a significant main effect of WC on spike weight of wheat plants; however the main effect of Si levels was non significant (Table 1). The interactive effect of Si levels and WC was significant on spike weight. Averaged over Si levels, spike weight was decreased from 0.80 g/spike in FC3 to $0.60 \mathrm{~g} /$ spike in FC2 and to $0.39 \mathrm{~g} / \mathrm{spike}$ in FC1. Spike weight in plants grown with $50 \mathrm{mg} / \mathrm{kg} \mathrm{Si}$ ranged from $0.36 \mathrm{~g} / \mathrm{spike}$ in FC1 to $0.77 \mathrm{~g} /$ spike in FC3. In plants grown with $150 \mathrm{mg} / \mathrm{kg}$ $\mathrm{Si}$, spike weight ranged from $0.40 \mathrm{~g} /$ spike in FC1 to $0.84 \mathrm{~g} /$ spike in FC3.

\section{Silicon Concentration and Uptake}

There were significant main and interactive effects of Si levels and WC on shoot Si concentration in wheat plants (Table 2). Silicon concentration in plants grown with $150 \mathrm{mg} / \mathrm{kg} \quad\left(\mathrm{Si}_{2}\right)$ was significantly more than in those plants grown with $50 \mathrm{mg} / \mathrm{kg}\left(\mathrm{Si}_{1}\right)$ Hattori et al., (2005) also reported that silicon concentration in leaf blades of sorghum was increased by Si application regardless 
of soil water regime. Silicon concentration in plants grown with FC3 was highest $(11.8 \mathrm{mg} / \mathrm{g})$, followed by those grown with FC2 $(10.0 \mathrm{mg} / \mathrm{g})$ and FC3 (8.99 mg/g). Baligar et al., (2001) reported that decreasing water availability under drought reduced the concentrations of mineral nutrients in crop plants. Silicon concentration in plants grown with $\mathrm{Si}_{1}$ ranged from $6.70 \mathrm{mg} / \mathrm{g}$ in $\mathrm{FC} 1$ to 8.81 $\mathrm{mg} / \mathrm{g}$ in FC3. In plants grown with $\mathrm{Si}_{2}, \mathrm{Si}$ concentration ranged from $11.28 \mathrm{mg} / \mathrm{g}$ to $14.82 \mathrm{mg} / \mathrm{g}$.

There were significant main and interactive effects of Si levels and WC on Si uptake by shoots (Table 2). The higher Si level $\left(\mathrm{Si}_{2}\right)$ caused a significant increase (1.75 fold) in $\mathrm{Si}$ uptake by wheat averaged over all three WC. Silicon uptake was significantly decreased as WC decreased gradually in soil. Jones and Handreck (1976) also reported that Si uptake increases with an increase in water contents as it is passively absorbed via mass flow. Silicon uptake had significant positive interaction with SDM at all levels of water supply (Fig. 3). Silicon uptake in plants grown with $\mathrm{Si}_{1}(50 \mathrm{mg} / \mathrm{kg})$ ranged from $24.3 \mathrm{mg} /$ pot (FC1) to $52.5 \mathrm{mg} /$ pot in FC3. In plants grown with $\mathrm{Si}_{2}(150$ $\mathrm{mg} / \mathrm{kg}), \quad$ Si uptake ranged from 49.4 $\mathrm{mg} /$ pot to $90.5 \mathrm{mg} /$ pot. Relative Si uptake in plants grown with FC1 and FC2 were $46 \%$ and $54 \%$ compared to that grown with FC3 at the $\mathrm{Si}_{1}$ level (Fig 2). In plants grown at the $\mathrm{Si}_{2}$ level, relative $\mathrm{Si}$ uptake was $54 \%$ and $71 \%$ compared to that grown with FC3. Higher water supply in soil caused a significant increase in $\mathrm{Si}$ uptake grown either with $\mathrm{Si}_{1}$ and $\mathrm{Si}_{2}$.

Table 1. Shoot dry matter and plant height of wheat grown with $50 \mathrm{mg} / \mathrm{kg}\left(\mathrm{Si}_{1}\right)$ and $150 \mathrm{mg} / \mathrm{kg}$ $\left(\mathrm{Si}_{2}\right)$ of $\mathrm{Si}$ at three levels of soil water contents viz. $50 \%, 75 \%$ and $100 \%$ of field capacity $\left(\mathrm{FC}_{1}\right.$, $\mathrm{FC}_{2}$ and $\mathrm{FC}_{3}$ ). Plants were harvested after $75 \mathrm{~d}$ of sowing. Values are means of three replications. Means followed by similar letters do not differ statistically at 0.05 probability.

\begin{tabular}{|c|c|c|c|c|c|c|}
\hline \multirow{2}{*}{$\begin{array}{l}\text { Soil Water } \\
\text { contents }\end{array}$} & \multicolumn{2}{|c|}{$\begin{array}{c}\text { Shoot dry matter } \\
\text { (g/pot) }\end{array}$} & \multicolumn{2}{|c|}{$\begin{array}{l}\text { Plant Height } \\
\text { (cm) }\end{array}$} & \multicolumn{2}{|c|}{$\begin{array}{l}\text { Spike weight } \\
\text { (g/spike) }\end{array}$} \\
\hline & Si1 & Si2 & Si1 & Si2 & Si1 & Si2 \\
\hline FC1 & $3.60 \mathrm{~d}$ & $4.39 \mathrm{c}$ & $37.7 \mathrm{c}$ & $41.1 \mathrm{c}$ & $0.36 \mathrm{~d}$ & $0.40 \mathrm{~d}$ \\
\hline FC2 & $4.80 \mathrm{bc}$ & $5.07 \mathrm{~b}$ & $46.3 \mathrm{~b}$ & $51.0 \mathrm{~b}$ & 0.59 bc & $0.65 \mathrm{~b}$ \\
\hline FC3 & $5.70 \mathrm{a}$ & $6.11 \mathrm{a}$ & $57.7 \mathrm{a}$ & $61.7 \mathrm{a}$ & $0.77 \mathrm{ab}$ & $0.84 \mathrm{a}$ \\
\hline LSD & \multicolumn{2}{|c|}{0.60} & \multicolumn{2}{|c|}{5.04} & \multicolumn{2}{|c|}{0.07} \\
\hline
\end{tabular}

Table 2. Si concentration and uptake of wheat grown with $50 \mathrm{mg} / \mathrm{kg}\left(\mathrm{Si}_{1}\right)$ and $150 \mathrm{mg} / \mathrm{kg}\left(\mathrm{Si}_{2}\right)$ of $\mathrm{Si}$ at three levels of soil water contents viz. $50 \%, 75 \%$ and $100 \%$ of field capacity $\left(\mathrm{FC}_{1}, \mathrm{FC}_{2}\right.$ and $\mathrm{FC}_{3}$ ). Plants were harvested after $75 \mathrm{~d}$ of sowing. Values are means of three replications. Means followed by similar letters do not differ statistically at 0.05 probability.

\begin{tabular}{lcccc}
\hline \multirow{2}{*}{$\begin{array}{l}\text { Soil Water } \\
\text { contents }\end{array}$} & \multicolumn{2}{c}{$\begin{array}{c}\text { Si concentration } \\
\text { (mg/g) }\end{array}$} & \multicolumn{2}{c}{$\begin{array}{c}\text { Si uptake } \\
\text { (mg/pot) }\end{array}$} \\
\cline { 2 - 6 } & Si1 & Si2 & Si1 & Si2 \\
\hline FC1 & $6.70 \mathrm{e}$ & $11.28 \mathrm{c}$ & $24.3 \mathrm{e}$ & $49.4 \mathrm{c}$ \\
FC2 & $7.33 \mathrm{e}$ & $12.80 \mathrm{~b}$ & $35.3 \mathrm{~d}$ & $64.9 \mathrm{~b}$ \\
FC3 & $8.81 \mathrm{~d}$ & $14.82 \mathrm{a}$ & $52.5 \mathrm{c}$ & $90.5 \mathrm{a}$ \\
\hline LSD & \multicolumn{2}{c}{0.92} & \multicolumn{2}{c}{8.29} \\
\hline
\end{tabular}




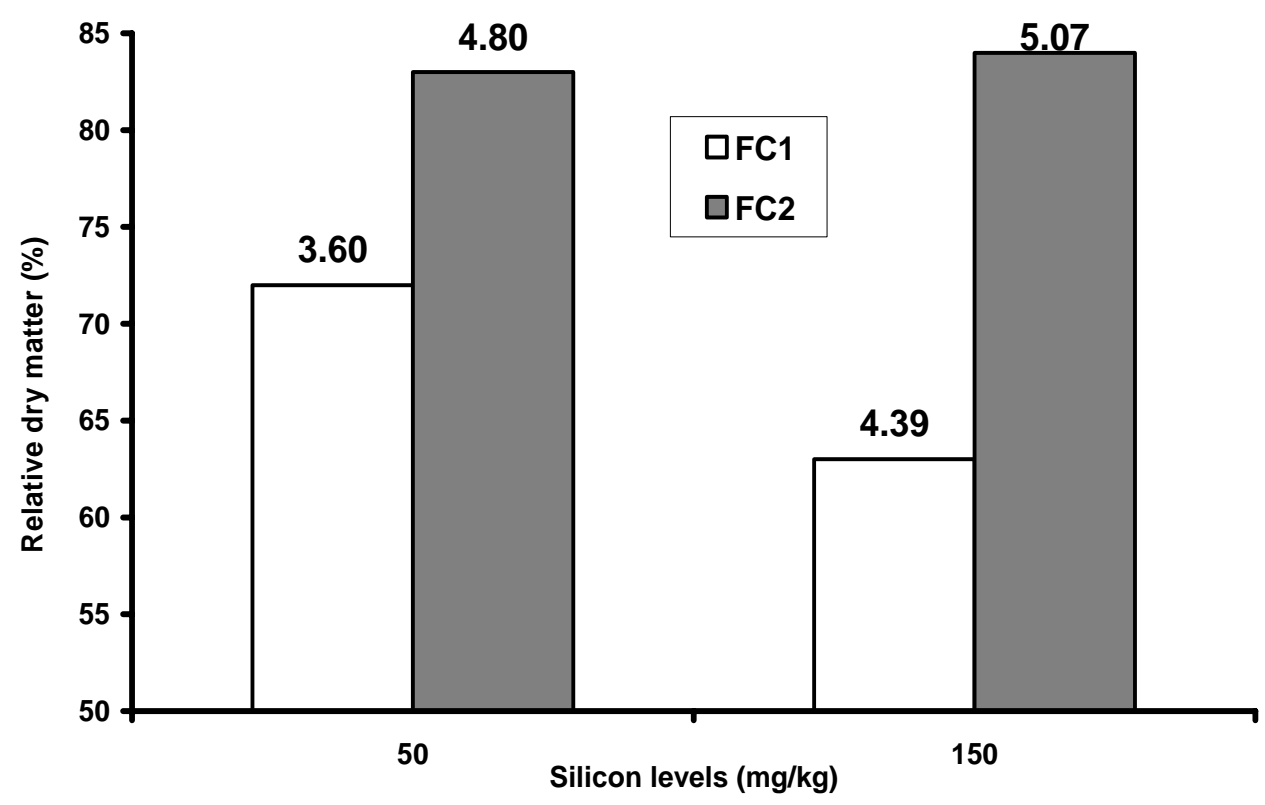

Fig. 1. Percent dry matter production of plants grown with $\mathrm{FC}_{1}$ and $\mathrm{FC}_{2}$ relative to those grown with $\mathrm{FC}_{3}$

Values on top of bars are absolute SDM and Si contents in $\mathrm{FC}_{1}$ and $\mathrm{FC}_{3}$

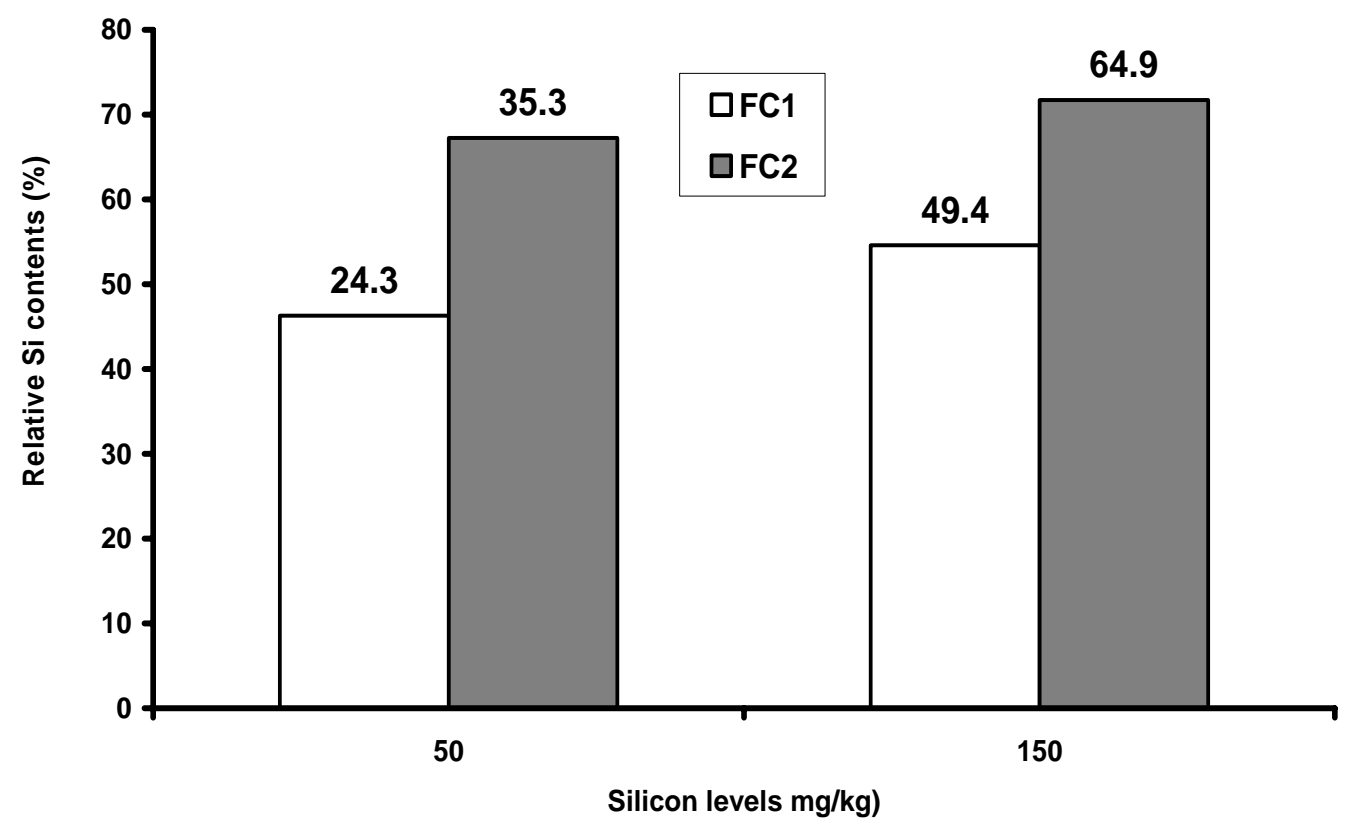

Fig. 2. Relative $\mathrm{Si}$ contents in plants grown with $\mathrm{FC}_{1}$ and $\mathrm{FC}_{2}$ compared with those grown with $\mathrm{FC}_{3}$

Values on top of bars are absolute SDM and Si contents in $\mathrm{FC}_{1}$ and $\mathrm{FC}_{3}$ 


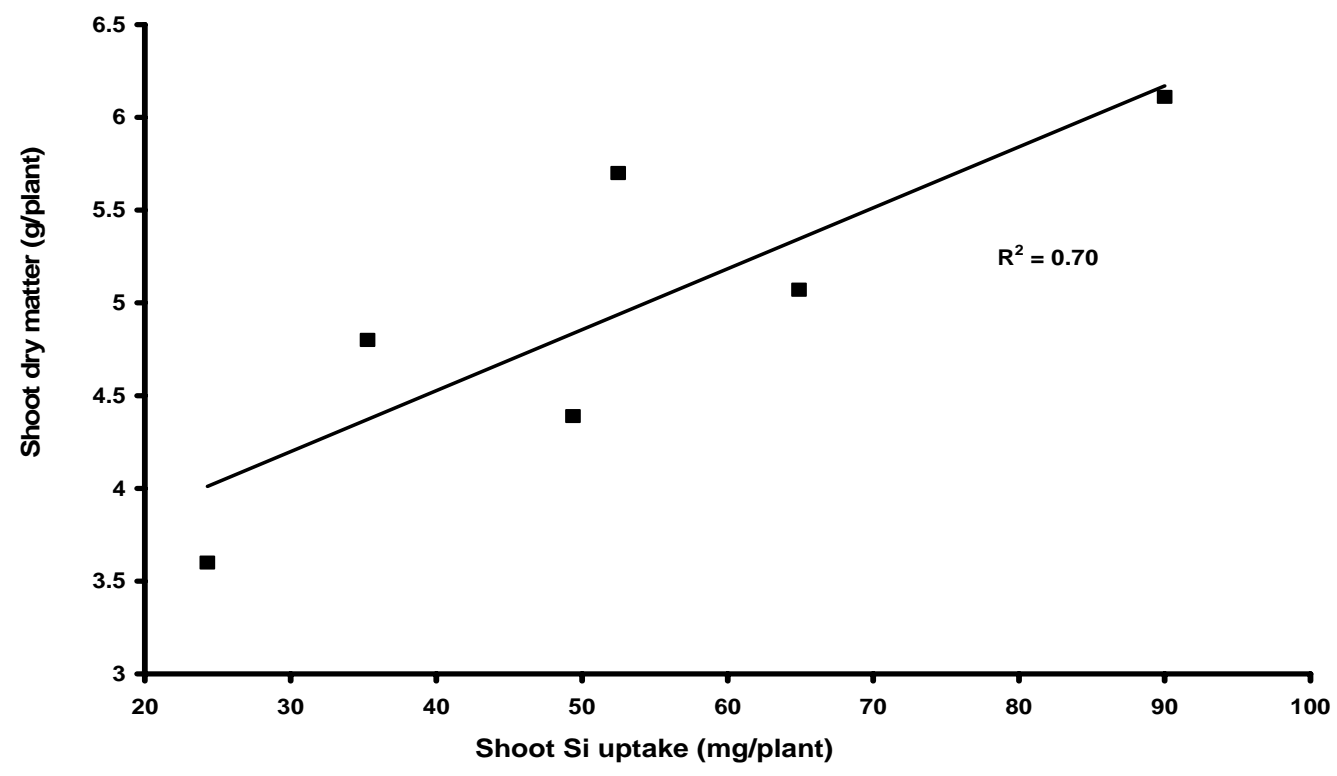

Fig. 3. Correlation of shoot dry matter with shoot Si uptake

\section{Conclusion}

Silicon application increased dry matter production of wheat at all soil water contents levels. Dry matter reduction in plants due to low water contents was significantly increased when $\mathrm{Si}$ was applied, indicating increased tolerance of wheat plants to drought. The mechanisms of drought tolerance are still unclear and must be explored in further experimentation.

\section{Acknowledgements}

The authors highly appreciate the financial help of Pakistan Agriculture Research Council, Islamabad (ALPSecretariat).

\section{References}

Akram, H. M., M. S. Iqbal, M. Saeed, A. Yar, A. Ali, K. A. Sahi and M. A. Nadeem. 2004. Drought tolerance studies of wheat genotypes. Pak. J. Biol. Sci. 7(1):90-92.

Alvarez, J., and L. E. Datnoff. 2001. The economic potential of silicon for integrated management and sustainable rice production. Crop Prot. 20:43-48.
Alvi, A. S. and M. Sharif. 1995. Arid zone agriculture research in Pakistan. Prog. Farming. 15: 5-12.

Aziz, T., M. A. Gill and Rahmatullah. 2002. Silicon nutrition and crop production: A review. Pak. J. Agric. Sci. 39 (3):181-187.

Baligar, V. C., N. K. Fageria and Z. I. He. 2001. Nutrient use efficiency in plants. Commun. Soil Sci. Plant Anal. 32:921-950.

Elliot, C. L., and G. H. Snyder. 1991. Autoclave-induced digestion for the colorimetric determination of silicon in rice straw. J. Agric. Food Chem. 39:1118-1119.

Epstein, E., 1999. Silicon. Annl. Rev. Plant Physiol. Plant Mol. Biol. 50:641-664.

Garg, B. K., U. Burman and S. Kathju. 2004. The influence of phosphorus nutrition on the physiological response of moth bean genotypes to drought. J. Plant Nutr. Soil Sci. 167: 503-508.

Gong, H. J., K. M. Chen, G. C. Chen, S. M. Wang and C. L. Zhang. 2003. Effect of silicon on growth of wheat 
under drought. J. Plant Nutr. 26(5):1055-1063.

Gunes, A., N. Cicek, A. Inal, M. Alpaslan, F. Eraslan, E. Guneri and T. Guzelordu. 2006. Genotypic response of chickpea (Cicer arietinum L.) cultivars to drought stress implemented at pre-and post-anthesis stages and its relations with nutrient uptake and efficiency. Plant Soil Environ. 52(8):368-376.

Hattori, T., S. Inanaga, E. Tanimoto, A. Lux, M. Luxova and Y. Sugimoto. 2003. Silicon induced changes in viscoelastic properties of sorghum root cell walls. Plant Cell Physiol. 44:743-749.

Hattori, T., S. Inanaga, H. Araki, P. An, S. Mortia, M. Luxova and A. Lux. 2005. Application of silicon enhanced drought tolerance in sorghum bicolor. Physiolgia Plantarum. 123: 459-466.

Jones, L. H .P. and K. A. Handreck. 1976. Silica in soils, plants and animals. Adv. Agron. 19:107-149.

Lux, A., M. Luxova, J. Abe, E. Tanimoto, T. Hattori and S. Inanaga. 2003. The dynamics of silicon deposition in the sorghum root endodermis. New Phytol. 158:437-441.

Lux, A., M. Luxova, T. Hattori, S. Inanaga and Y. Sugimoto. 2002. Silification in sorghum (Sorghum bicolor) cultivars with different drought tolerance. Physiologia Plantarum. 115:87-92.

Ma, J. F. 2004. Role of silicon in enhancing the resistance of plants to biotic and abiotic stresses. Soil Sci. Plant Nutr. 50:11-18.
Matoh, T., S. Murata and E. Takahashi. 1991. Effect of silicate application on photosyntheis of rice plants (in Japanese). Jpn. J. Soil Sci. Plant Nutr. 62:248-251.

Melo, S. P., G. H. Korndorfer, C. M. Korndorfer, R. M. Q. Lana and D. G. Santan. 2003. Silicon accumulation and water deficient tolerance in grasses. Scientia Agricola. 60:755759.

Mitani, N. and J. F. Ma. 2005. Uptake system of silicon in different plant species. J. Exp. Bot. 56:1255-1261.

Rafi, M. M., E. Epstein and R. H. Falk. 1997. Silicon deprivation causes physical abnormalities in wheat (triticum aestivum L.). J. Plant Physiol. 151:497-501.

Rodrigues, F. A., F. X. R. Vale, G. H. Korndorfer, A. S. Prabhu, L. E. Datnoff, A. M. A. Oliveira and L. Zambolim. 2003. Influence of silicon on sheath blight of rice in Brazil. Crop Prot. 22:23-29.

Russel, D. F. and S. P. Eisensmith. 1983. MSTAT-C. Crop Soil Sci. Dept. Michigan State Univ., USA.

Samarah, N., R. Mullen and S. Cianzio. 2004. Size distribution and mineral nutrients of soybean seeds in response to drought stress. J. Plant Nutr. 27:815-835.

Tahir, M. A., Rahmatullah, T. Aziz, M. Ashraf, S. Kanwal and M. A. Maqsood. 2006. Beneficial effects of silicon in wheat (Triticum aestivum L.) under salinity stress. Pak. J. Bot. 38(5):1715-1722. 